\title{
Literature Review of V. S. Naipaul's Works
}

\author{
Chunjuan Guo ${ }^{1, a}$ \\ ${ }^{1}$ Shantou University, Shantou Guangdong, 515063 \\ acjguo@stu.edu.cn \\ a email
}

Keywords: V.S. Naipaul, Postcolonial study, Literature review, Cultural identity

\begin{abstract}
V. S. Naipaul, awarded the Nobel Prize in Literature in 2001, is one of the most distinguished and prolific contemporary writer. Most of his representative works are relative to the construction of cultural identity v cultural confrontation and ideological confusion which is significant to the postcolonial study. The thesis falls into the following two parts. With the introductory part paving the way, the first part introduces the literature review of Naipaul's works abroad, and the second part explores the studies on Naipaul's novels in China.
\end{abstract}

\section{Introduction}

The 20th century witnesses dramatic changes in the world: the two World Wars, the withdrawal of colonial mandates, the economic liberalization and the social and cultural transformation associated with globalization. Owing to these, a vast number of people are attracted to leave their homeland and emigrate to other countries. As various races and cultures begin to mix, confrontation with the existing cultural structure and ideologies always causes people's sense of alienation and otherness, which ultimately throw them into the dilemma of identity crisis. Therefore, identity issue - both individual and collective - has become ceaselessly salient during the process of cultural alienation, adaptation and assimilation for the exiled intellectuals, among which V. S. Naipaul is a typical and significant one. Naipaul is an Indian by blood, a Trinidadian by birth and a Briton by citizenship. His literary works, which spans half a century, are generally based on postcolonial contexts and multicultural locations. His growing awareness of the complexities and difficulties of cultural differences, which is exhibited in his literature, leads to his perplexity of identity. To a large extent, his works can be seen as the result of the worldwide political, cultural and economic changes of the $20^{\text {th }}$ century. Therefore, meticulous interpretation and analysis of his works may shed light upon how to communicate with other cultures, how to deal with one's identity crisis and how to maintain a balanced self among various cultures.

Vidiadhar Surajprasad Naipaul (1932- ), one of the most prominent and prolific contemporary writers, has bagged various prestigious prizes during his more than forty years of writing, among which the most glorious is the 2001 Nobel Laureate in Literature for "having united perceptive narrative and incorruptible scrutiny in works that compel us to see the presence of suppressed histories" (as cited in Thomas, 2003, p. 228).[1] Being regarded as a typical and significant postcolonial writer, Naipaul takes a strong interest in the exploration of colonial problems and confusions resulted from the withdrawal of imperial order. 


\section{The Research Background of Literature}

Naipaul's great literature achievement has brought him into widespread public and critical scrutiny. Critical response in the Western world has almost been at pace with his publications and by now it has made remarkable achievement, especially in the English-speaking West and India. In Yang Zhongju's monologue on Naipaul's works, he divides Naipaul's literary creation into three periods: 1950-1970, 1970-2000, after 2000. I agree and adopt his division.

During 1950 to 1970, Naipaul has published three books, namely The Mystic Masseur (1957), The Suffrage of Elvira (1958) and Miguel Street (1959), among which The Mystic Masseur has received the John Llewellyn Rhys Memorial Prize. During 1950 to 1970, for Naipaul, the world just took notice of him instead of recognizing him. Therefore, there is hardly any in-depth study on Naipaul's works during this period. Only a few brief book reviews could be found, which aim to introduce and summarize rather than interpret and analyze his works. For example, Harrington (2003) presents the biographical information on Naipaul and introduces his early books The Mystic Masseur and Miguel Street in his essay NAIPAUL, [Sir] V [idiadhar] S [urajprasad].

In the second period from 1970 to 2000, with the advancement of Naipaul's other works, Naipaul's literary writings as well as his life experience have gradually come to the fore of the reader's and critic's attention. The earliest monograph on V. S. Naipaul is probably an American critic Paul Theroux' V. S. Naipaul: An Introduction to His Works, which is published in London in 1972. This book makes a comparatively comprehensive introduction to Naipaul's life and his works, which could be seen as one of the pioneer works in the study of Naipaul. Later, other researchers have gradually added their own interpretations to the analysis of Naipaul. One of the important monologues is Bruce King's first edition of V.S. Naipaul in 1993. In his book V. S. Naipaul, Bruce King gives high praise to Naipaul's literary accomplishment and analyzes the synthesis of cultures embodied in Naipaul's writings. Other monologues have also come out in succession, such as Michael Thorpe’s V. S. Naipaul in 1976, Selwyn Reginald Cudjoe’s V. S. Naipaul: A Material Reading in 1988. Meanwhile, a series of journal criticism rose. For example, in 1998, an article entitled The House that Jack Did not Build: Textual Strategies in V.S. Naipaul's "The Enigma of Arrival Tarantino”, by Tarantino, examines how the landscapes and events described in Naipaul's "The Enigma of Arrival" are used to create "moral tension" and also explores the direct and indirect ways of expression reflected in Naipaul’s works (Tarantino, 1998, p. 169).[2]

While being well acclaimed, Naipaul and his works have stimulated disagreement at the same time. From 1970 to 2000, Naipaul and his works has been the target of acrimonious criticism. Some critics excoriate him for being “a despicable lackey of neo-colonialism” (Wee, 2003, p. 155) [3] and "a cold and sneering prophet” (Ramphal, 2003, p. 30).[4] The disagreeable voices generally come from the Third World. However, in the eyes of Western critics, Naipaul's depictions of the society and people of the Third World are trustworthy and objective.

In the third period, after 2000, especially in the light of the Nobel Prized for Literature in 2001, Naipaul has received worldwide recognition and been acknowledged as an outstanding writer of great talent and statue. Therefore, more and more critics participate in the study of Naipaul and his works from varying theoretical perspectives and diversified orientations.

Many critics explore Naipaul's life experience and his works mainly from the post-colonial perspective. In 2003, Bruce King's second edition of V.S. Naipaul came out. Inspired by his first edition of V. S. Naipaul, King takes a further analysis on Naipaul's novels covering the years from 1959 to 2001. The book delineates the bicultural or multicultural features embodied in the postcolonial contexts on which Naipaul's works are based. King (2003) also illustrates that Naipaul focuses on "Individual in colonial societies" while many postcolonial writers appear mostly 
“concerned with ideas and groups” (p. 28).[5] Taking King's ideas a step further in his book Naipaul's Strangers, Dagmar Barnouw (2003) continues to discuss the "cultural plurality" and "cultural values" in Naipaul's works, which is, argues by the author, "the most important and difficult challenge to the late modernity" (p. 1).[6] One of the latest monographs that touch upon duality, identity and culture in Naipaul's works goes to D.N. Ganjewar's Philosophic Vision in the Novels of V.S. Naipaul, which is first published in 2008. Ganjewar (2008) makes a detail analysis of a varied range of Naipaul's "philosophic visions" embedded in his works and claims that Naipaul is "one of the most pessimistic and bleak visions among the contemporary writers" (p. 26).

Narrative strategy employed in Naipaul's writing to strengthen his literary power is another topic that has been frequently discussed by critics. For instance, Imraan Coovadia's Authority and Authorship in V.S. Naipaul published in 2009 centers on the rhetorical features involved in Naipual's works. Imraan Coovadia elaborates in his monologue that the rhetorical features, namely the patterns of Virgilian allusion and misquotation, the "cold jokes", the use of motifs, the Naipaulian ekphrasis, and the sensory intensity of Naipaulian description, are essential to the Novelist's literary power. Based on the detail analysis, Imraan Coovadia (2009) attempts to explore the authority and authorship in Naipaul's works and how the "Naipaulian rhetoric" constructs "his authority” (p. 4).[8]

In addition to the monologues stated above, a great number of journal articles also contribute to the study of Naipaul and his works, among which some are valuable and will be enumerated as follows. In 2008,V. S. Naipaul: Childhood and Memory written by Mahabir was published in Journal of Caribbean Literatures. It demonstrates that Naipaul's relation with his father and his childhood experience is of significance on his "escape motif", which becomes the main part of Naipaul's literary endeavors and "continues in the rest of his works" (Mahabir, 2008, p. 16).[9] Some recent journal articles concentrate on the comparison between Naipaul and other postcolonial writers like Catherine Lanone's Negotiating Colonial Contradition: E.M. Foster's and V.S. Naipaul's Negative Landscapes publiched in 2011 and Weihsin Gui's Post-heritage narratives: Migrancy and travelling theory in V.S. Naipaul's The Enigma of Arrival and Andrea Levy's Fruit of the Lemon in 2012. As suggested by these titles, comparative studies between Naipaul and other writers such as E. M. Forster, Andrea Levy and so on have been conducted by different critics.

As is shown above, critical study on Naipaul and his works has shown diversified orientations and adopted varying analytical perspectives in the West. However, compared to the studies abroad, the domestic critical study on Naipaul's work in China started much later.

Compared to the studies abroad, the Chinese study on Naipaul is much limited. According to professor Yang Zhongju (2009), the researches on Naipaul's works in China are divided into two periods: before 2000 and after 2000.[10]

\section{The Research Progress of Naipaul Literature}

Before 2000, Naipaul and his work are almost unnoticed in China. Only one of Naipaul's novels, Miguel Street, was published in 1992. And few in-depth criticisms in regard to Naipaul and his work could be found before 2000. There are only some brief book reviews on Naipaul and his work in the journals like Foreign Literature and Recent Developments. The earliest book review that could be found on Naipaul's works is an article, by Zhang Zhongzai (1986), entitled Looking for Truth and Beauty - a Reading of V. S. Naipaul's A House for Mr. Biswas, which is published in Foreign Literature in 1986. This article makes a brief introduction to the story of a man's pursuit of a house in A House for Mr. Biswas.

After 2000, Naipaul's work gradually became a hot topic in China. According to a rough 
estimation, by the end of 2011, seven of Naipaul's novels, his Indian trilogy and his two autobiographical books consisting of Letters Between A Father and Son and A Writer's People have been published in China. Chinese scholars are showing increasing interests in Naipaul's work. In the mainland of China, by the end of 2011, there have been about three monologues on Naipaul and his works, and over nine doctoral dissertations and 43 master theses devoted to the study of Naipaul. Likewise, in these monologues and academic theses, Chinese scholars and graduates have demonstrated different attitudes and approaches towards Naipaul's literary works.

One of the important books is Zhou Min's monologue Postcolonial Identi/ties: A Study of V. S. Naipaul's Major Novels, which is based on her Ph. D. dissertation. Drawing on postcolonial theories as well as contemporary cultural theories, Zhou Min has done a thorough research on Naipaul's major novels at different periods consisting of A House for Mr. Biswas, The Mimic Men, The Enigma of Arrival and A Way in the World. Zhou Min (2011) attempts to analyze, critically and creatively, the reasons why Naipaul's work is so much "praised" and yet suffered so much "diatribe" at the same time (p. i).[11] Her acute observation hits the nail on the head and it is of great value for this thesis writing. Apart from Zhoumin's great endeavor, many other scholars also devote to the identity issues in Naipaul's work like Lei Yanni. Grounded in the postcolonial context, her Ph. D. dissertation Empire Inclination and Nativism Consciousness: A Case Study on Naipaul and his works (2010)is to show the duality, hybridity, cultural conflicts and confrontation, implicitly and explicitly, embodied in Naipaul's works.

Diasporic motif in Naipaul's works is also a hot topic of the criticism. Examples can be found in Du Weiping's dissertation. In her Ph. D. dissertation, Du Weiping (2004) makes a detail analysis on Naipaul's works from the perspective of "disapora", mainly based on the "post-colonialism", "spatial theory" and "the third space theory" (p. 1).[12] There are other critics who discuss the diasporic motif in Naipaul's works such as Wang Gang. He explores both the similarities and dissimilarities of diasporic features in Naipaul's nine works relating to India in his Ph. D. dissertation Floating Around Reality and Illusion - Research into Diasporic Features of Naipaul's Writing Concerning India.

\section{Conclusion}

In addition to the above-mentioned books and dissertations, there are about 230 journal critiques written on different works of Naipaul, which focus respectively on the postcolonial, feminist, cultural, historical and spatial dimension of Naipaul's writing.

Judging from the above literature review among the Chinese critics, the division between the pro and con of Naipaul's writing is not as obvious as in the international circle. Furthermore, less critical attention is distributed to Naipaul's nonfictions and his rhetorical strategies.

\section{References}

[1] Thomas, S. (2003). V. S. Naipaul. In Bill Schwarz (Ed.). West Indian Intellectuals in Britain. Manchester, England: Manchester University Press.

[2] Tarantino, E. (1998). The House that Jack Did not Build: Textual Strategies in V.S. Naipaul's “The Enigma of Arrival”. ARIEL: A Review of International English Literature, 29 (4), 169-84.

[3] Wee, C. J. W. - L. (2003). Culture, Empire, and the Questions of Being Modern. Lanham, Maryland: Rowman \& Littlefield.

[4] Ramphal, J. K. P. (2003). V. S. Naipaul's Empty Chapel: His Background, Works, and Vision the Third World. Canada: Sugarcane. 
[5] King, B. A. (2003). V.S. Naipaul. New York: Palgrave Macmillan.

[6] Barnouw, D. (2003). Naipaul’s Strangers.Bloomington, Indiana: Indiana University Press.

[7] Ganjewar, D. N. (2008). Philosophic Vision in the Novels of V. S. Naipaul. India: Adhyayan.

[8] Coovadia, I. (2009). Authority and Authorship in V. S. Naipaul. Publisher:Palgrave Macmillan.

[9] Mahabir, K. (2008). V. S. Naipaul: Childhood and Memory. Journal of Caribbean Literatures,5, 1-18.

[10] Yang, Zhongju. (2009). Naipaul: Cross-boundary life and Multi-perspective Narration. Shanghai: New Oriental Press. In Chinese.

[11] Zhou, Min. (2011). Postcolonial Identi/ties: A Study of V.S Naipaul's Major Novels. Shanhai: Shanhai Foreign Education Publication.

[12] Du, Weiping. (2004). The Political Study on Naipaul. Beijing: Beijing Foreign Studies University. In Chinese. 